\title{
A STUDY ON CUSTOMER AWARENESS OF SLICEPAY AMONG COLLEGE STUDENTS IN CHENNAI
}

\author{
Dr. S. Sivaprakkash \\ Assistant Professor, Department of Commerce, College of Science \& Humanities, \\ SRM Institute of Science \& Technology, Vadapalani Campus, Chennai, Tamil Nadu, India
}

\begin{abstract}
The connotation of the people towards money has been shifted due to digital credit platform. Today in a metropolitan city like Chennai, the middle-class people who are the floating population are having an urge to settle in proper part of the city. But however, this movement of people has brought in lot of complications like uncontrolled spending, credit fraud, payment defaulting, etc. The accelerated growth of digital credit has increased the transaction efficiency. Till recently, the college students were using the digital credit for a small a sum as Rs. 100 to over eighty thousand rupees as per their credit limits. The research has been carried out among the college students in Chennai City. This study analyses whether students are aware of digital credit platform. It also focuses on whether the services provided by Slicepay is meeting the expectations and fulfilling them.
\end{abstract}

Keywords: Awareness, Credit, Expectation, Income, Slicepay, Quality

Cite this Article: S. Sivaprakkash. A Study on Customer Awareness of Slicepay among College Students in Chennai. International Journal of Advanced Research in Management (IJARM). 12(1). 2021. pp. 1-11.

https://iaeme.com/Home/issue/IJARM?Volume $=12 \&$ Issue $=8$

\section{INTRODUCTION}

A customer is one that purchases useful for utilization and not for resale or business reason. The shopper is a person who pays some measure of cash for the thing required to devour merchandise and enterprises. All things considered; buyers assume a crucial job in the financial arrangement of a country. Without shopper request, makers would need one of the key inspirations to deliver to offer to customers. The purchaser likewise frames some portion of the chain of dissemination. As of late in advertising rather than advertisers creating wide segment profiles and Fisio-realistic profiles of market portions, advertisers have begun to take part in customized showcasing, authorization promoting, and mass customisation. Making a potential customer to recognize or recall a brand when faced with a purchase decision has become a hectic task in today's competitive world. The brand awareness decides the level of purchaser acknowledgment of an item by its name. Making brand aware is most important in advancing 
another item or reviving more established brand. Familiarity with the brand may incorporate the characteristics that recognize the item from its opposition. To a great extent because of the ascent of the Internet, customers are moving increasingly more towards turning out to be prosumer, buyers who are additionally makers (frequently of data and media on the social web), impact the items made (for example by customisation, crowd funding or distributing their inclinations), effectively partake in the creation procedure, or utilize intuitive items. Customers are the fundamental financial elements of an economy. Every one of the customers expend products and enterprises straightforwardly and in a roundabout way to amplify fulfilment and utility. Customers have constrained salary and by which they need to fulfil their most extreme (utility is the need fulfilling limit of an item). By and large, shopper implies an individual in particular; be that as it may, purchasers will comprise of a specific individual, a gathering of people, establishments and so forth.

Digital credit being an innovative product and represents an absolutely a new wave of accessing loans and becomes a healthy competitor to traditional way of credit lending. The Consultative Group to Assist the Poor (CGAP) in their 2016 report confessed that the digital credit is instant, automated and remote. These three points differentiated digital credit system from traditional credit system. As per the CGAP Report, the time taken from the approval of loan application to disbursement of loan is mostly less than 24 hours. The determination of creditworthiness and decisions regarding loan approval are determined by automated processes rather than by people. The interactions between lenders and borrowers take place over digital channels, rather than in person. The digital credit is advantageous over existing bank credit in the ways of calculating credit score, reduced transaction costs, instants loan approval and disbursement and product customization. The journey of digital technologies is miraculous in the way that it is shattering down the blockades to access the finance at an extraordinarily rapid pace, creating up new accessible ways for reaching the poor people in the remotest corners of the country and connecting them for the very first time to wider digital marketplace. These technologies are rattling the old school of thoughts in lending the money in both creative and challenging ways that makes the money lenders both government and private companies to think out of box the possibilities and means of achieving financial inclusion.

By and large the demands of the people are never ending and is an infinite loop. As the salaries of the customers are growing in arithmetic proportions, the needs of the customers are galloping in geometric proportions. Be it a necessity or luxurious products or services, the list never ends. Only once in a blue moon, we can find a self-sustained human being. People are searching for various sources of funds to fulfil their need. Especially college students preparing their first ever bucket list are need of filthy rich pocket money from their parents. In pursuit of that searching for petty loans increased. To target this segment several online credit platforms emerged. Peer-to-peer (P2P) lending helps students to get loans directly from individuals by cutting out the banks. P2P lending has greatly increased its adoption as an alternative method of financing. The college students to satisfy their desires began the search of digital credit through P2P mode. Digital credit has become a contemporary to the traditional money lending by brick-and-motor financial institutions. It serves as a platter for accessing loans and impact is poles apart compared with traditional microcredit. Slicepay is one such digital credit platform which supports students financially. Since there is paucity on the customer awareness of digital credit platforms, there exists a time-limited window for conducting research in this space. As digital credit platforms are just now being rolled out, there exist immediate opportunities to study the level of penetration of the platforms to the grass-root level and their reach out to the last mile.

Slicepay is a digital credit platform which was founded in the year 2016 Rajan Bajaj and Deepak Malhotra with a mission to simplify payments for college students in Bangalore 
later was expanded to Chennai, Mumbai and other major cities across India. Slicepay offers small amount of loans to students based on their digital shopping transactions. Slicepay facilitates all the process required to get credit. The traditional commercial banks use several parameters, including account statements and CIBIL score. But the main aim of Slicepay is to lend to customers who don't have a salary slip or a CIBIL score which leads to greater financial inclusion.
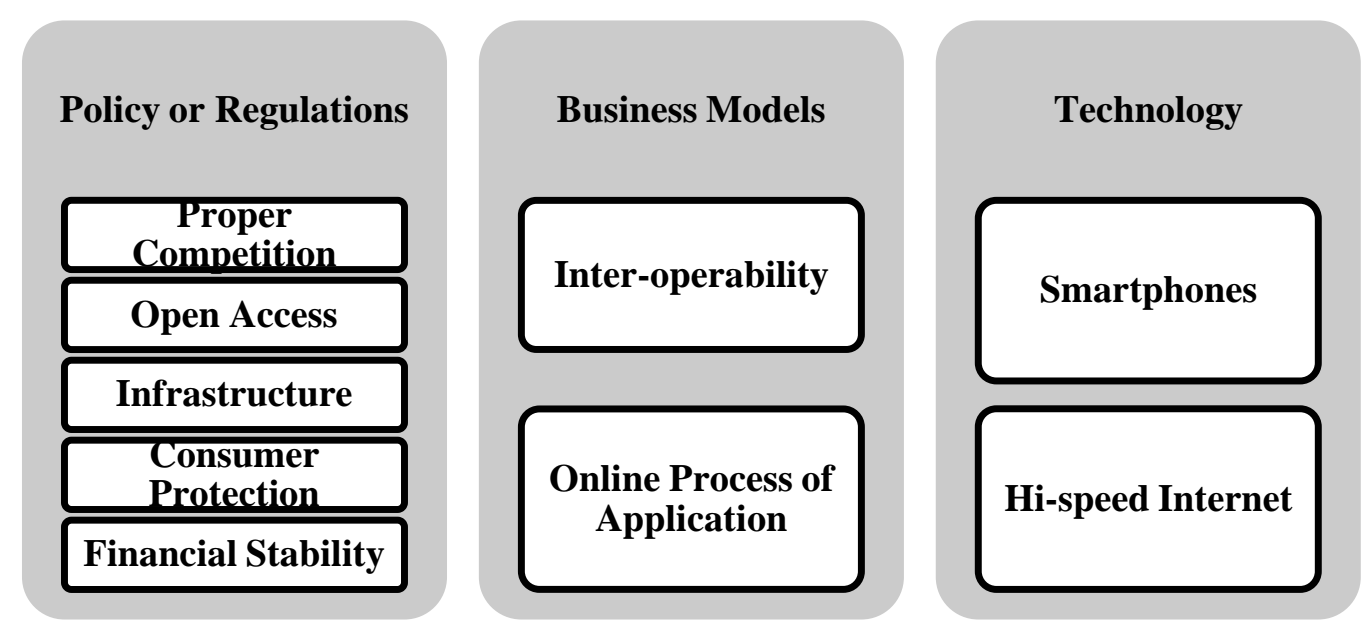

Figure 1 Digital Ecosystem ${ }^{1}$

\section{REVIEW OF LITERATURE}

Aparajita Gupta, (2019) identified that millennials (early 2000's) are the most important customer for Slicepay as the younger generation in India loves to spend more of their money on experiences rather than purchasing of products.

Dhirendra Tripathi, (2019 Livemint) in his article found that Slicepay provides an impetus to the students for online purchasing of goods and services. The digital credit company offers collateral free loan upto an amount of Rs. 60,000 and can be of various tenures. The company's assertion is that college students are big consumers of food, clothes, travel and entertainment but chances of not having cash-in-hand to make purchase of their choices immediately is on a higher scale.

Nirmalya Behera, (2017 Business Standard) in his article pinpointed that there is galloping increase in number of youngsters and volume of trade in online shopping correlated with manifold increase in appetite for credit leading to a rise in alternative lenders. Slicepay setup the college students to purchase goods and services on equated monthly instalments thus leaving no stone unturned to grab this opportunity.

Parada \& Bull, (2014); Mujeri, (2015); Manyika et al., (2016) have suggested that digital credit products have the inherent capacity to reach the bottom-most customers that banks realized after long-tenure of service. They also reach marginalized populations who does not have the required documentation to access formal financial services and poor populations without resources or time to meet formal banking requirements. Digital credit products may also help unbanked populations to reach out to informal money lenders and local savings group as sources of credit.

Parada \& Bull, (2014); Costa et al., (2016) have identified that the modern credit lending products make use of non-traditional data like mobile phone activity, social media data and

\footnotetext{
${ }^{1}$ Adopted from CGAP Annual Report - 2016, pp. 3
} 
mobile money account transactions as a database to estimate the creditworthiness of the college students. This will enable digital credit applications to provide the potential to the people to access various forms of credit who do not have traditional credit scores or those who are considered to be risky by traditional lenders.

\section{SIGNIFICANCE OF THE STUDY}

The main purpose of the study is to analysis customer awareness of Slicepay with special regard to digital credit platform. The study also focuses on the customers perception on various services provided by Slicepay and what are the other factors which customers except from slicepay. The study concerns on various promotional tools for creating customer awareness.

\section{OBJECTIVES OF THE STUDY}

- To analyze the customer awareness of Slicepay application.

- To study the consumer's service quality in Slicepay application.

- To study the customer expectation about Slicepay application.

- To suggest ideas for improving Slicepay application.

\section{MATERIALS AND METHODS}

The study is a descriptive research analyzing data and characteristics about population being studied. For analyzing the awareness of Slicepay among college students who are considered as social units, the sample was clustered as Arts and Science College, Engineering College and Medical College in Chennai. The sample size for the study was 300 students which was selected through Random Sampling Method. A structured questionnaire was circulated among the samples through Google Forms. The researcher has employed Paired t-test (for Gender) and Chi-Square to find relationship between Customer Awareness Factors and Demographic Variables. ANOVA was also deployed to find relationship between service quality parameters, customer expectation factors and demographic variables.

\section{LIMITATIONS OF THE STUDY}

The study was carried out only in Chennai city and the facts relabeled in the study may not be generalized to other cities in India.

\section{DISCUSSIONS AND RESULTS}

\subsection{Customer Awareness of Slicepay Application - Percentage Analysis}

\section{a) Demographic Profile of the Sample}

Male customers are more attracted to the digital credit platform (Slicepay) then female customers. $87 \%$ of the respondents fall in the age bracket of $19-22,8 \%$ of the respondents are at the age group of above 22 and $5 \%$ are at the age group of 18 because it is the initial stage of getting credit. $42 \%$ of the respondents belongs to the expenditure group of $1000-1500,37 \%$ of the respondents belongs to the expenditure group of below 1000 and $21 \%$ of the respondents belongs to the expenditure group of above $1500.67 \%$ of the respondents are from the Urban, $23 \%$ of the respondents are from the Semi Urban and 10\% of the respondents are from the Rural. $90 \%$ of the respondents belongs to UG, $5 \%$ of the respondents belongs to PG and $5 \%$ of the respondents belongs to Diploma. 50\% of the respondents belongs to Arts \& Science, $44 \%$ of the respondents belongs to Engineering and $6 \%$ of the customers belongs to Medical. Students are also allowed to recharge their Paytm wallets using Slicepay. 


\section{b) Awareness about Slicepay}

From the survey conducted it was found that $70 \%$ of the respondents preferred Slicepay as their credit platform. 64\% of the respondents came to know about the Slicepay by friends and 69\% of the respondents opines that Slicepay is poor in advertisement. $78 \%$ of the respondents preferred Slicepay as the market leader among the competitors in digital credit platform in India. 59\% of the respondents are interested to suggest Slicepay to their friends and colleague to satisfy their financial needs. $44 \%$ of the respondents require credit ranging between Rs. 5000 and Rs. 10000.

\section{c) Customer Satisfaction on Slicepay Service Quality}

From the survey conducted it was evident that $51 \%$ of the respondents are extremely delighted with the quality of service which is being provided by Slicepay. $49 \%$ of the respondents are satisfied with the process of getting problems resolved by the Slicepay. 35\% of the respondents are satisfied with the time taken by customer service representatives to solve the problem in Slicepay. $31 \%$ of the respondents are highly satisfied with the knowledge of customer service representatives in Slicepay. 32\% of the respondents are satisfied with the wait time for the questions to be answered by Slicepay.

\section{d) Customer Expectations on Slicepay}

From the survey conducted it was found that $39 \%$ of the respondents requires reduction of rate of interest while 37\% agrees on reduction of bank transfer fee in Slicepay. 34\% of the respondents requires 24*7 customer service in Slicepay. 33\% of the respondents are agreeing to increase credit limit in Slicepay. 31\% of the respondents want extension of no-cost EMI in Slicepay. $37 \%$ of the respondents are agreed with the smooth and free flow of information from the Slicepay team to the customers.

H01: There is no significant difference between customer awareness factors and demographic variables.

Ha1: There is significant difference between customer awareness factors and demographic variables.

\begin{tabular}{|c|c|}
\hline Customer Awareness Factors & Options \\
\hline $\begin{array}{l}\text { Frequency of people talking about } \\
\text { Slicepay }\end{array}$ & $\begin{array}{l}\text { Very Often, Often, A Few Times, Once or Twice, I haven't } \\
\text { heard people talking about it }\end{array}$ \\
\hline Your thought on Slicepay & Positive, Negative, Neutral \\
\hline Your credit limit (in Rs.) & $\begin{array}{l}5000-10000,10000-20000,20000-30000,30000-40000, \text { Above } \\
40000\end{array}$ \\
\hline Market leader & Slicepay, Krazybee, mPokket \\
\hline
\end{tabular}

Table 1 Paired Sample t-test Analysis for Customer Awareness of Slicepay Application

\begin{tabular}{|c|c|c|c|c|c|c|c|c|}
\hline & \multicolumn{5}{|c|}{ Paired Differences } & \multirow{3}{*}{$\mathbf{t}$} & \multirow{3}{*}{ df } & \multirow{3}{*}{ 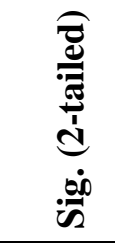 } \\
\hline & \multirow[t]{2}{*}{ 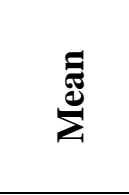 } & \multirow{2}{*}{ कृ } & \multirow{2}{*}{ 离 } & \multicolumn{2}{|c|}{$\begin{array}{c}\text { 95\% Confidence } \\
\text { Interval of the } \\
\text { Difference }\end{array}$} & & & \\
\hline & & & & Lower & Upper & & & \\
\hline Pair 1 & -1.967 & 1.285 & 0.074 & -2.113 & -1.821 & -26.51 & 299 & $0.000^{\#}$ \\
\hline Pair 2 & -0.967 & 0.957 & 0.055 & -1.075 & -0.858 & -17.501 & 299 & $0.000^{\#}$ \\
\hline Pair 3 & -0.153 & 1.722 & 0.099 & -0.349 & 0.042 & -1.542 & 299 & 0.124 \\
\hline Pair 4 & -0.013 & 0.758 & 0.044 & -0.099 & 0.073 & -0.305 & 299 & 0.761 \\
\hline
\end{tabular}




\section{Interpretation}

From Table-1, it is inferred that the null hypothesis is rejected for Pair-1 and Pair-2 as the pvalue is less than 0.05 , which means that there is gender bias associated with knowing on people talking about Slicepay (Pair-1) and opinion about Slicepay (Pair-2). But in case of Pair-3 and Pair-4, the null hypothesis is accepted as the p-value is more than 0.05 , stating that there is no gender partiality in the credit requirement (Pair-3) and brand positioning of Slicepay as the Market Leader in Digital Credit Platform in India (Pair-4).

Table 2 Chi-Square Analysis for Customer Awareness of Slicepay Application

\begin{tabular}{|c|c|c|c|}
\hline \multicolumn{4}{|c|}{ Age Vs. Frequency of people talking about Slicepay } \\
\hline & Value & df & Asymp. Sig. (2-sided) \\
\hline Pearson Chi-Square & 7.687 & 8 & 0.465 \\
\hline Likelihood Ratio & 7.347 & 8 & 0.500 \\
\hline Linear-by-Linear Association & 0.643 & 1 & 0.423 \\
\hline N of Valid Cases & 300 & & \\
\hline \multicolumn{4}{|c|}{ Age Vs. Your thought on Slicepay } \\
\hline & Value & $\mathrm{df}$ & Asymp. Sig. (2-sided) \\
\hline Pearson Chi-Square & 11.025 & 4 & $0.026^{@}$ \\
\hline Likelihood Ratio & 13.704 & 4 & 0.008 \\
\hline Linear-by-Linear Association & 3.694 & 1 & 0.055 \\
\hline N of Valid Cases & 300 & & \\
\hline \multicolumn{4}{|c|}{ Age Vs. Your credit limit (in Rs.) } \\
\hline & Value & df & Asymp. Sig. (2-sided) \\
\hline Pearson Chi-Square & 13.335 & 10 & 0.206 \\
\hline Likelihood Ratio & 19.324 & 10 & 0.036 \\
\hline Linear-by-Linear Association & 3.650 & 1 & 0.056 \\
\hline $\mathrm{N}$ of Valid Cases & 300 & & \\
\hline \multicolumn{4}{|c|}{ Age Vs. Market leader } \\
\hline & Value & df & Asymp. Sig. (2-sided) \\
\hline Pearson Chi-Square & $32.382^{\mathrm{a}}$ & 4 & $0.000^{@}$ \\
\hline Likelihood Ratio & 25.194 & 4 & 0.000 \\
\hline Linear-by-Linear Association & 7.948 & 1 & 0.005 \\
\hline $\mathrm{N}$ of Valid Cases & 300 & & \\
\hline \multicolumn{4}{|c|}{ Locality Vs. Frequency of people talking about Slicepay } \\
\hline & Value & df & Asymp. Sig. (2-sided) \\
\hline Pearson Chi-Square & 11.028 & 8 & 0.200 \\
\hline Likelihood Ratio & 11.004 & 8 & 0.201 \\
\hline Linear-by-Linear Association & 0.024 & 1 & 0.876 \\
\hline N of Valid Cases & 300 & & \\
\hline \multicolumn{4}{|c|}{ Locality Vs. Your thought on Slicepay } \\
\hline & Value & df & Asymp. Sig. (2-sided) \\
\hline Pearson Chi-Square & 2.454 & 4 & 0.653 \\
\hline Likelihood Ratio & 2.589 & 4 & 0.629 \\
\hline Linear-by-Linear Association & 0.990 & 1 & 0.320 \\
\hline $\mathrm{N}$ of Valid Cases & 300 & & \\
\hline \multicolumn{4}{|c|}{ Locality Vs. Your credit limit (in Rs.) } \\
\hline & Value & df & Asymp. Sig. (2-sided) \\
\hline Pearson Chi-Square & 24.969 & 10 & $0.005^{\circledR}$ \\
\hline Likelihood Ratio & 26.239 & 10 & 0.003 \\
\hline Linear-by-Linear Association & 0.060 & 1 & 0.807 \\
\hline $\mathrm{N}$ of Valid Cases & 300 & & \\
\hline
\end{tabular}




\begin{tabular}{|c|c|c|c|}
\hline & Value & df & Asymp. Sig. (2-sided) \\
\hline Pearson Chi-Square & 2.378 & 4 & 0.667 \\
\hline Likelihood Ratio & 2.153 & 4 & 0.708 \\
\hline Linear-by-Linear Association & 0.103 & 1 & 0.748 \\
\hline $\mathrm{N}$ of Valid Cases & 300 & & \\
\hline \multicolumn{4}{|c|}{ Specialization Vs. Frequency of people talking about Slicepay } \\
\hline & Value & df & Asymp. Sig. (2-sided) \\
\hline Pearson Chi-Square & 14.321 & 8 & 0.074 \\
\hline Likelihood Ratio & 16.029 & 8 & 0.042 \\
\hline Linear-by-Linear Association & 1.232 & 1 & 0.267 \\
\hline $\mathrm{N}$ of Valid Cases & 300 & & \\
\hline \multicolumn{4}{|c|}{ Specialization Vs. Your thought on Slicepay } \\
\hline & Value & $\mathrm{df}$ & Asymp. Sig. (2-sided) \\
\hline Pearson Chi-Square & 17.548 & 4 & $0.002^{@}$ \\
\hline Likelihood Ratio & 23.877 & 4 & 0.000 \\
\hline Linear-by-Linear Association & 1.603 & 1 & 0.205 \\
\hline $\mathrm{N}$ of Valid Cases & 300 & & \\
\hline \multicolumn{4}{|c|}{ Specialization Vs. Your credit limit (in Rs.) } \\
\hline & Value & df & Asymp. Sig. (2-sided) \\
\hline Pearson Chi-Square & 39.566 & 10 & $0.000^{@}$ \\
\hline Likelihood Ratio & 42.367 & 10 & 0.000 \\
\hline Linear-by-Linear Association & 3.898 & 1 & 0.048 \\
\hline $\mathrm{N}$ of Valid Cases & 300 & & \\
\hline \multicolumn{4}{|c|}{ Specialization Vs. Market leader } \\
\hline & Value & df & Asymp. Sig. (2-sided) \\
\hline Pearson Chi-Square & 16.202 & 4 & $0.003^{@}$ \\
\hline Likelihood Ratio & 14.105 & 4 & 0.007 \\
\hline Linear-by-Linear Association & 0.390 & 1 & 0.532 \\
\hline $\mathrm{N}$ of Valid Cases & 300 & & \\
\hline
\end{tabular}

\section{Interpretation}

From Table-2, for the variables, Age Vs. Your thought on Slicepay and Age Vs. Market leader, the null hypothesis is rejected as the p-value is less than 0.05. Even on the basis of age parameter, different age group people have different views about Slicepay and its competitors. Respondents in the age group of 18-22 have a positive opinion about Slicepay Application.

From Table-2, for the variables Locality Vs. Your credit limit, the null hypothesis is rejected as the $\mathrm{p}$-value is less than 0.05 . The locality where the people live decide the amount of credit availed through Slicepay Application. People living in rural areas are availing more of credit facility ranging from Rs. 5000 to Rs. 40000 compared to urban people.

In case of Specialization, for the variables, Specialization Vs. Your thought on Slicepay, Specialization Vs. Your credit limit and Specialization Vs. Market leader, the null hypothesis is rejected as the p-value is less than 0.05. Arts and Science Degree students have positive opinion on Slicepay compared to Engineering and Medicine. The Arts and Science Students avail more credit facility and consider Slicepay Application as the market leader.

\subsection{Consumer's Service Quality in Slicepay Application - ANOVA}

The service quality parameters taken for the study are problem solving process, quality of customer service representatives, time taken to solve the problem, knowledge of customer service representatives, turnaround time for the problem solved and overall service quality. 
H02: There is no significant relationship between service quality parameters and demographic variables.

$\mathbf{H}_{\text {a2: }}$ There is significant relationship between service quality parameters and demographic variables.

Table 3 Analysis of Variance for Consumer's Service Quality in Slicepay Application

\begin{tabular}{|c|c|c|c|c|c|}
\hline \multicolumn{6}{|c|}{ Age Vs. Service Quality of Slicepay } \\
\hline & Sum of Squares & df & Mean Square & $\mathbf{F}$ & Sig. \\
\hline Between Groups & 2.434 & 2 & 1.217 & 0.719 & 0.488 \\
\hline Within Groups & 502.871 & 297 & 1.693 & & \\
\hline Total & 505.305 & 299 & & & \\
\hline \multicolumn{6}{|c|}{ Income Vs. Service Quality of Slicepay } \\
\hline & Sum of Squares & $\mathrm{df}$ & Mean Square & $\mathrm{F}$ & Sig. \\
\hline Between Groups & 25.191 & 2 & 12.595 & 7.792 & $0.001^{\$}$ \\
\hline Within Groups & 480.115 & 297 & 1.617 & & \\
\hline Total & 505.305 & 299 & & & \\
\hline \multicolumn{6}{|c|}{ Locality Vs. Service Quality of Slicepay } \\
\hline & Sum of Squares & $\mathrm{df}$ & Mean Square & $\mathrm{F}$ & Sig. \\
\hline Between Groups & 8.060 & 2 & 4.030 & 2.407 & 0.092 \\
\hline Within Groups & 497.245 & 297 & 1.674 & & \\
\hline Total & 505.305 & 299 & & & \\
\hline \multicolumn{6}{|c|}{ Education Vs. Service Quality of Slicepay } \\
\hline & Sum of Squares & $\mathrm{df}$ & Mean Square & $\mathrm{F}$ & Sig. \\
\hline Between Groups & 7.365 & 2 & 3.682 & 2.196 & 0.113 \\
\hline Within Groups & 497.940 & 297 & 1.677 & & \\
\hline Total & 505.305 & 299 & & & \\
\hline \multicolumn{6}{|c|}{ Specialization Vs. Service Quality of Slicepay } \\
\hline & Sum of Squares & $\mathrm{df}$ & Mean Square & $\mathrm{F}$ & Sig. \\
\hline Between Groups & 11.119 & 2 & 5.560 & 3.341 & $0.037^{\$}$ \\
\hline Within Groups & 494.186 & 297 & 1.664 & & \\
\hline Total & 505.305 & 299 & & & \\
\hline
\end{tabular}

\section{Interpretation}

From Table-3, the null hypothesis related to the relationship between the service quality parameters and three demographic variables (age, locality and education) are in the acceptance region as $p$-value is greater than the 0.05 and two demographic variables (income and specialization) are rejected, as the p-value is lesser than 0.05 . This implies that the service quality parameters have no significant relationships with age, locality and education, except for income and specialization.

\subsection{Customer Expectation about Slicepay Application - ANOVA}

The customer expectation factors taken for the study are: reduction of rate of interest, reduction of bank transfer fee, $24 \times 7$ customer service, increase in credit limit, extension of no cost EMI and smooth and free flow of information 
Ho3: There is no significant relationship between customer expectation and demographic variables.

$\mathbf{H}_{\mathbf{a} 3:}$ There is significant relationship between customer expectation and demographic variables.

Table 4 Analysis of Variance for Customer Expectation about Slicepay Application

\begin{tabular}{|c|c|c|c|c|c|}
\hline \multicolumn{6}{|c|}{ Age Vs. Customer Expectation About Slicepay } \\
\hline & Sum of Squares & df & Mean Square & $\mathbf{F}$ & Sig. \\
\hline Between Groups & 10.554 & 2 & 5.277 & 8.115 & $0.000^{\wedge}$ \\
\hline Within Groups & 193.129 & 297 & .650 & & \\
\hline Total & 203.683 & 299 & & & \\
\hline \multicolumn{6}{|c|}{ Income Vs. Customer Expectation About Slicepay } \\
\hline & Sum of Squares & df & Mean Square & $\mathrm{F}$ & Sig. \\
\hline Between Groups & 16.819 & 2 & 8.409 & 13.366 & $0.000^{\wedge}$ \\
\hline Within Groups & 186.864 & 297 & 0.629 & & \\
\hline Total & 203.683 & 299 & & & \\
\hline \multicolumn{6}{|c|}{ Locality Vs. Customer Expectation About Slicepay } \\
\hline & Sum of Squares & df & Mean Square & $\mathrm{F}$ & Sig. \\
\hline Between Groups & 0.593 & 2 & 0.296 & 0.433 & 0.649 \\
\hline Within Groups & 203.090 & 297 & 0.684 & & \\
\hline Total & 203.683 & 299 & & & \\
\hline \multicolumn{6}{|c|}{ Education Vs. Customer Expectation About Slicepay } \\
\hline & Sum of Squares & $\mathrm{df}$ & Mean Square & $\mathrm{F}$ & Sig. \\
\hline Between Groups & 2.398 & 2 & 1.199 & 1.769 & 0.172 \\
\hline Within Groups & 201.285 & 297 & 0.678 & & \\
\hline Total & 203.683 & 299 & & & \\
\hline \multicolumn{6}{|c|}{ Specialization Vs. Customer Expectation About Slicepay } \\
\hline & Sum of Squares & df & Mean Square & $\mathrm{F}$ & Sig. \\
\hline Between Groups & 8.064 & 2 & 4.032 & 6.122 & $0.002^{\wedge}$ \\
\hline Within Groups & 195.619 & 297 & 0.659 & & \\
\hline Total & 203.683 & 299 & & & \\
\hline
\end{tabular}

\section{Interpretation}

From Table-4, the null hypothesis related to the relationship between the customer expectation factors and two demographic variables locality and education) are in the acceptance region as p-value is greater than the 0.05 and three demographic variables (age, income and specialization) are rejected, as the p-value is lesser than 0.05 . This implies that the customer expectation factors have no significant relationships with, locality and education, except for age, income and specialization.

\section{SUGGESTIONS}

The following suggestions are made for improving customer awareness:

- Advertising plays a very important role in increasing the awareness and in reminding the customer about the services offered by Slicepay.

- Brand promotion can be done by sponsoring Cultural Events, Workshops conducted at the Colleges.

- Viral marketing through message, online pop-up advertisements have to be enforced in regular intervals and in proper media which would reach a large number of potential customers. 
- More cash back should be provided to the customers to encourage them and motivate them for using Slicepay as their credit platform.

- Customers should be contacted at a regular interval through phone calls and asking them if they are facing any problems with the digital credit platform.

- Interest Rate and Bank Transfer Fee's should be reduced for the customers to satisfy them and it leads to more referral.

\section{CONCULSION}

The main aim for doing this study was to understand customers awareness of Slicepay among college students in Chennai. In the yesteryears, the digital credit has been expeditiously proliferated in developing economies particularly in India, yet there is virtually no quantitative research to examine its effects. Digital credit provides several considerable enhancements compared to traditional credit like large reductions in transactions costs, instant loan approval and disbursement by using non-traditional data to generate credit scores. This leads to an expansion in the consumer base. Yet the current products that are available are largely high interest rate, short-term loans that look very similar to payday loans in the developed world. In this environment, easy access to high interest rate loans is likely to have heterogeneous effects, potentially providing liquidity in times of need for people.

From the study it has proved that the brand of Slicepay has got good awareness level among the customers in Chennai. As there exists a lot of big brands in the digital credit platform for students it is really important that there is a good brand name maintained by Slicepay Team. This is the only way out of better their market for the services. With just the College ID, Aadhar Card or PAN Card, Slicepay completes the entire KYC process of the students. The digital algorithms which they follow cull out data from the customer's mobile and social networking platforms to decide whether the student is eligible for the card or not. All the customers who were selected as the samples heard the name of brand quite well and this is a good sign to the firm. Especially in the field of digital credit, only if the brand is popular among customers the firm can accept great demand for the services. So, it was clear that the brand of Slicepay services is quite well known and this is a sign of bright future for the brand.

\section{REFERENCES}

[1] CGAP - Annual Report (2016)

[2] Cook, T. \& McKay, C. (2015). How M-Shwari works: The story so far. CGAP.

[3] Costa, A., Deb, A., \& Kubzansky, M. (2016). Big Data, Small Credit: The Digital Revolution and its impact on Emerging Market Customers. Omidyar Network.

[4] Manyika, J., Lund, S., Singer, M., White, O., \& Berry, C. (2016). Digital Finance for All: Powering Inclusive Growth in Emerging Economies. McKinsey Global Institute. Retrieved 4 January 2017, from http://www.mckinsey.com/ /media/McKinsey/Global\%20Themes/Employment\%20and\%20G rowth/How\%20digital\%20finance\%20could\%20boost\%20growth\%20in\%20emerging\%20eco nomies/MG-Digital-Finance-For-All-Full-report-September-2016.ashx

[5] Fintech in India - Powering a digital economy - By, KPMG in India

[6] Digitally Delivered Credit: Consumer Protection Issues and Policy Responses to New Models of Digital Lending - By, AFI CEMC Working Group Publication 
[7] Digital Credit Emerging Markets - By, Eilin Francis, Joshua Blumenstock, Jonathan Robinson

[8] A Digital Credit Revolution - By, Michelle Kaffenberger, Edoardo Totolo, Matthew Soursourian

[9] Parada, M. \& Bull, G. (2017). In the Fast Lane: Innovations in Digital Finance. International Financial Corporation. Retrieved 6 January 2017, from https://www.ifc.org/wps/wcm/connect/d2898b80440daa039453bc869243d457/In+The+Fast+ Lane++Innovations+in+Digital+Finance+IFC.pdf?MOD=AJPERES

[10] http://bwdisrupt.businessworld.in/article/SlicePay-a-Buy-Now-Pay-Later-Platform-ForCollege-Students-Crosses-2M-in-Annual-Run-Rate-Within-9-Months-of-Launch/29-10-2016107585/

[11] https://craft.co/slicepay

[12] https://evans.uw.edu/policy-impact/epar/research/review-digital-credit-products-andregulations 